\title{
Terrorismo e relações internacionais
}

\author{
ARGEMIRO PROCÓPIO*
}

\section{Introdução}

O terrorismo das perseguições, das injustiças e das intolerâncias jamais constituiu problema menor para a sociedade humana. Apesar disto, a quase totalidade dos Estados, salvo raríssimas exceções, sempre pretendeu considerá-lo como patologia marginal. Bem recentemente, a luta contra o terrorismo internacional pontuava-se na busca de altas tecnologias, criação de complexos contra ataques de mísseis, armas nucleares, agentes químicos, biológicos etc.

As estratégias dos Estados na cruzada contra o terror, principalmente nos países centrais, desde a queda do muro de Berlim, transformaram-se em apáticas e desacreditadas indústrias antiterror. Envolvidos por interesses financeiros da indústria de informação e produção de mísseis, os serviços de inteligência confiaram demais na alta sofisticação tecnológica. Esqueceram-se que além da aparente vitória dos computadores contra o terror, coisas outras existem por detrás dos biombos da mundialização; que a terra é feita de interesses. Noutras palavras, ignoraram a História e suas velhas lições, inclusive a Guerra de Tróia.

Todo o aparato defensivo de altíssima tecnologia, no qual o contribuinte do mundo inteiro tanto dinheiro enterra, acabou burlado por métodos simples atrelados ao sofisticado terrorismo financeiro, engendrados por redes humanas dentro do território do país considerado inexpugnável e locomotiva da economia mundial.

O cavalo de Tróia do terror, exibido bem no coração dos Estados Unidos, pela dramaticidade de sua simbologia, pelo anonimato de seus autores, pelo sensacionalismo da mídia na exploração das imagens da destruição, acabou maior que o "presente de grego". Espalhou o medo e o pânico em escala jamais concebida. Seus amargos frutos estão por ser colhidos em qualquer lugar. Daí o esforço analítico para apresentar ao leitor da Revista Brasileira de Política Internacional o presente esboço do complexo mapeamento teórico em busca das tendências e causas estruturais da violência do terror na comunidade das nações.

\section{Novo teste da hegemonia política}

A demonstração do poderio bélico dos Estados Unidos - de seus gigantescos porta-aviões, de sua portentosa força aérea, de suas divisões com

* Professor Titular em Relações Internacionais da Universidade de Brasília. 
guerreiros fantasiados de invencibilidade - tão enaltecido após a II Guerra Mundial, continua penetrando diuturnamente nos lares estadunidenses e nos países sob sua órbita de influência. Por meio da televisão e da eficientíssima engrenagem do aparato cultural chamado Hollywood, inclusive a derrota no Vietnã é lembrada como acidente casual de passado remoto.

Nos países comunistas, o aparato de poder era exposto mais parcimoniosamente, ou seja, no primeiro de maio e nas suas respectivas datas nacionais. Toda esta força conhecida, incapaz de enfrentar o terrorismo que atingiu em cheio os símbolos da segurança e da prosperidade do capitalismo norteamericano, ou seja, o Pentágono e as duas torres em Nova Iorque, terá contra si as iras da manipulada opinião pública estadunidense.

O sacrifício dos limites impostos pelo estado de direito e pelo estado democrático na luta contra o terror fere o que há de nobre, precioso e sagrado na alma da democracia americana, ou seja, o respeito às liberdades individuais. Oporse ao terror consoante a filosofia democrática e a ética cristã, respeitar os valores que se procura salvar e deixá-los fora do alcance dos terroristas é elogiável. Mas reagir com violência semelhante, ou seja, converter a campanha contra o terrorismo em uma espécie de outra guerra santa, que faz vítimas inocentes com os bombardeios ao Afeganistão, desvenda as ambigüidades e a hipocrisia da pax americana.

\section{O colapso da moralidade}

O colapso da moralidade convencional e o colapso dos princípios da segurança humana em que também se assentam os pilares do Estado-nação levam a crer que, de todas as deficiências da política antiterror dos Estados Unidos nas relações internacionais, a mais grave é a desconsideração das desigualdades. Vale dizer as desigualdades como causas estruturais, fomentadoras do terrorismo internacional.

A forma pouco sofisticada, nada técnica politicamente falando, como começou a ser implementada a caça aos terroristas, revela que o mundo permanece vítima de cenas repetidas, de ações que nunca deram certo no passado. Por exemplo, em 20 de agosto de 1998, aviões dos Estados Unidos invadiram o espaço aéreo afegão acreditando eliminar Osama bin Laden, apontado como responsável pelos atentados contra representações diplomáticas estadunidenses em Dar es-Salam e Nairobi, perpetrados treze dias antes.

Está sendo levado a cabo no combate ao terror, sem paralelo na história da humanidade, um novo teste da força da hegemonia política nas relações internacionais. O terror é um fenômeno global e seu combate há de levar em consideração amplo espectro de posturas, longe do unilateralismo praticado pela 
maior potência mundial. Pede trabalho conjunto, solidariedade e acentuada aproximação respeitosa com outras culturas e sociedades. A luta contra o terror exige preenchimento do déficit da human intelligence nos serviços de informação; verdadeiros exercícios com humildade para aprender lições com outros povos, inclusive saber falar, entender suas línguas e outras manifestações culturais ${ }^{1}$.

A revanche armada como resposta à transnacionalidade do terror semeia inseguranças. Faz temer pelo futuro das fronteiras nacionais: corta a confiança no ethos da responsabilidade compartida e no princípio do respeito mútuo. Tudo isto tonifica a quase secular doutrina intervencionista dos Estados Unidos. Em resumo, a violência da força militar até hoje quase nada fez para cortar as raízes do terrorismo mundial.

Com ou sem o poderio de vigilância dos Estados Unidos, a porosidade das fronteiras nacionais sempre foi fato. Também não é de agora que são tecidas pelo hedonismo consumista as frustrações entre os povos com baixo poder aquisitivo. A violência e o desperdício ensinados nos filmes, e em outros canais da cultura dominante, fortalecem as redes sustentadoras do terror. Infelizmente quase nunca levam-se em conta as inconsistências das ações contra o ódio étnico, de classe ou religioso.

As debilidades estruturais fomentadas pela corrupção doméstica e pela injustiça externa são argumentos a favor da luta de classes. São reforçadas como nunca pelas disparidades do sistema internacional, pelos juros da dívida externa e inclusive pelo dólar, papel transformado em dinheiro sem lastro ouro, fincado no mundo inteiro. As elites, tanto dos países pobres quanto dos países ricos, precisam somar esforços na luta contra as diferenças entre classes sociais, atenuando a patologia do consumismo capitalista, antes que o terror se espalhe em versões ainda mais assassinas que as até agora conhecidas.

A ética antiterror sabe que a paz é igualmente fruto da justiça. Que o novo nome da paz deveria ser desenvolvimento sustentável, emprego e comida para todos. A problemática vista por este ângulo encara o terrorismo como fenômeno político por excelência e, como tal, precisa ser combatido. Suas assimetrias, igualmente atacadas com remédios políticos amargos, se necessário.

O terror possui capacidades, vários fôlegos. Cogitar em abatê-lo com a ação única da guerra é um equívoco. As tensões sociais, o ódio étnico, a discriminação racial, a exclusão das maiorias das benesses do capitalismo, o fascismo, o anti-semitismo, a xenofobia, o nacionalismo doentio, os fundamentalismos religiosos judeus e islâmicos, entre outros, são como sangue nas veias do terror da contemporânea história humana. Ao se desejar a paz, para que ela permaneça e faça parte desta mesma história, não há como deixar a mobilização contra o terror ser conduzida por mentores da guerra. 


\section{O TIAR e a generalização do conflito}

Face à ousadia dos bárbaros gestos do terrorismo internacional, pouco adianta retirar da cova, como fez a reativa diplomacia brasileira, o Tratado Interamericano de Assistência Recíproca (TIAR). A Organização dos Estados Americanos (OEA), jamais se desfez das cicatrizes do Destino Manifesto. O comportamento político da Organização, tradicional acólito do mandonismo dos Estados Unidos, em sessão convocada pela diplomacia presidencial de Fernando Henrique Cardoso, aprovou como esperado, a aplicação do TIAR como troco às investidas do terror em Washington e Nova Iorque. Assinado em 1947 na excapital brasileira, desmoralizou-se quando do conflito argentino com o Reino Unido.

Na Guerra das Malvinas, em 1982, o TIAR não pôde ser invocado porque o agressor era a Argentina. Entretanto, na luta contra o terror, a lógica do TIAR, se ressuscitada, favorecerá a generalização do conflito. O risco que se corre é de vê-lo ser invocado na cruzada contra o internacionalizado narcoterrorismo na Amazônia ou na tríplice fronteira entre Brasil, Paraguai e Argentina ${ }^{2}$. No novo contexto da luta antiterrorista, atentado destruidor como o ocorrido anos atrás contra a Associação Judaica em Buenos Aires, se repetido dentro de qualquer país signatário, também servirá de argumento para a invocação do TIAR.

Como se não bastasse a subalternidade ocorrida com a Base de Alcântara, a postura do Itamaraty em relação à instalação do escritório do US Secret Service na capital paulista sem o consentimento do Congresso Nacional espelha debilidades no serviço exterior. Mais uma vez o Brasil sofre nas relações internacionais as contradições e deficiências causadas pelos equívocos dos formuladores de sua política externa.

A recomposição do esqueleto do TIAR e seu anacrônico renascimento proposto como agrado aos Estados Unidos da América pela diplomacia brasileira terminaram sendo vistos, externamente, como barganha comprometida pela maioria dos latino-americanos dentro da Doutrina Monroe, agora revigorada pela multilateralização. Internamente, como nova demonstração do velho alinhamento incondicional. Tantos gestos de dependência ameaçam a tradição pacifista brasileira de ir para os ares. A luta antidrogas "para inglês ver" do governo tampouco consegue estancar o crescente número de vítimas do narcoterrorismo. Assim as coisas caminham: democracia e segurança, apesar de anos como temas fundamentais da agenda da política externa desgraçadamente não representaram progresso a favor do fortalecimento do estado de direito em canto algum do continente. Nem mesmo depois do discurso "Século das Américas", do Presidente Bush em Miami, em agosto de 2000 .

Os defensores da ressurreição do TIAR esqueceram-se que há anos existe contra o terrorismo continental a Resolução 1080. Aprovada na quinta sessão plenária da Organização dos Estados Americanos (OEA), realizada em Washington, 
em 5 de junho de 1991, a Resolução pretende resolver, por meio de "decisões que forem consideradas apropriadas" tudo que ameace a estabilidade da democracia representativa regional. Apesar de sua existência, o narcoterrorismo não pára de flagelar a sociedade das Américas ${ }^{3}$.

\section{A economia das redes do terror}

A falta do cálculo político racional na luta contra as diversas modalidades do terror, há décadas, obriga a sociedade latino-americana a carregar enorme peso. O narcoterrorismo de quotidiana presença no continente ceifa vidas. Corrompe descaradamente o legislativo, o judiciário e o executivo. Suas operações no palco interno e externo, sofisticadas e rudimentares, difusas e, às vezes, muito concentradas, criaram redes de apoio ao terror da corrupção espalhadas pelas Américas, pela Europa e por partes do Oriente Médio. Segmento considerável destas redes estende-se para dentro do território dos Estados Unidos, o maior consumidor de drogas e, também, o maior receptador dos dividendos dos bilionários negócios da corrupção e do narcotráfico. Tais redes, de dificílima penetração, ligadas à lavagem do dinheiro sujo, podem servir também ao ódio étnico, racial e religioso, entre outros. Neste caso, a culpa não é só do fundamentalismo islâmico, transformado, depois do fatídico 11 de setembro, em bode expiatório de quase todas as desgraças mundiais.

A impostura dos centros bancários funcionando nos paraísos fiscais desafia a propalada ética antiterror que se quer implantar nas relações internacionais. Não são desmantelados porque Wall Street e centros financeiros como os de Frankfurt, Londres, Paris, Zurique e Milão, entre outros, necessitam da convivência em refúgios da ilegalidade presentes nos paraísos fiscais e nos interesses que abrigam. Protegidas de regulamentação e impostos, as melhores praças de proteção ao capital financiador do crime organizado estão no Panamá, Belice, Costa Rica, Antilhas Holandesas, Bermudas, Bahamas, Ilhas Turks e Caicos, Ilhas Virgens, Anguilla, São Vicente, Santa Lúcia, Kitts-Nevis, Libéria, Madeira, Suíça, Luxemburgo, Ilhas Cayman, Andorra, Mônaco, Sark e Jersey, Irlanda, Lienchtenstein, Chipre, Líbano, Dubai, Barhein, Uruguai, Maurício, Malta, Singapura, Hong Kong, Macau, Samoa Ocidental, Vanuatu, Ilhas Cook, Ilhas Marshal e Ilhas Mariana $^{4}$.

O incondicional amparo governamental a interesses financeiros levou os Estados Unidos a rejeitar o acordo sobre a lavagem de dinheiro proposto pela Organização para a Cooperação e Desenvolvimento Econômico (OCDE). O lucro dos negócios envolvendo narcóticos e contrabando de armas dá passos gigantescos: aproveita do poder dos interesses que favorece a rede bancária e os fundos de hedge nos paraísos fiscais. Poder que igualmente usufrui da abordagem unilateralista da política externa dos Estados Unidos. 
O dinheiro dos corruptos roubado da sociedade brasileira é tanto que foge do imaginário. A título de comparação, as somas desviadas do INSS por Georgina de Freitas e seus comparsas, somadas ao que roubou dos cofres públicos o bando do juiz Nicolau dos Santos Neves, são superiores à fortuna de Osama bin Laden estimada em trezentos milhões de dólares. O monumental ganho obtido com tráfico de material bélico e de drogas ilícitas depositado em bancos dos Estados Unidos e em dezenas de paraísos fiscais já nominados neste texto movimentam múltiplas engrenagens da economia dos Estados Unidos. O terror organizado abastece e supre suas necessidades aproveitando-se das rachaduras da crise ética e moral emersas nas debilidades do tempo da unipolaridade. Rachaduras que, de forma direta ou indireta, amparam a desgraça responsável pelo soterramento de tantas e tantas pessoas inocentes sob os escombros das duas torres símbolos da prosperidade capitalista.

Caso a prometida luta contra a lavagem de dinheiro circunscrevase apenas aos momentos da febre de indignação contra ações terroristas perpetradas nos Estados Unidos, o terror organizado desfrutará de enormes facilidades para obtenção do dinheiro ilegal, lavado ou não. Com fartura de capital é possível sustentar quaisquer estruturas corruptoras e cooptadoras, presentes dentro e fora das fronteiras estadunidenses. Tal fartura tem se transformado em presente de mão beijada da globalização aos grupos terroristas.

$\mathrm{Na}$ reconfiguração hodierna das formas de luta pela segurança humana contra o terrorismo urge mostrar a ineficácia das velhas receitas da repressão movida por golpes militares, tortura e desrespeito aos direitos humanos. Oxalá, a política de contenção ao comunismo inspirada na Doutrina Truman, gerada na Guerra Fria, não reencarne na política internacional de contenção ao terrorismo. Pouco importa se sob o nome de operação justiça infinita, liberdade duradoura ou outros!

Em face dos tantos insucessos do combate ao ódio, inclusive ao terror da fome, ao terror da corrupção, ao terror das desigualdades, a análise do generalizado aumento dos conflitos nas relações internacionais necessita ir além das conveniências dos paradigmas aplicados pelas diplomacias das grandes potências e das que giram em sua órbita.

A imprensa internacional, tanto a falada quanto a escrita, geralmente capta o que julga valer aos seus interesses. Raramente sugere políticas públicas em favor da pacífica solução das controvérsias. Controvérsias igualmente sopradoras do terror. Falta educação para os marginalizados e preço justo aos produtos agrícolas para que a população rural da periferia mundial não continue na tentação da produção da papoula sustentadora da economia dos talibãs, como ocorre no Afeganistão. Na luta contra a produção de cocaína nos países amazônicos, prevenção e repressão deveriam significar a aplicação da justiça. Justiça é a única saída capaz de atenuar a patologia da violência sustentáculo do terror. 


\section{O big stick no combate ao terror}

A reação do executivo estadunidense em face dos recentes atentados terroristas merece ser aquilatada à luz de recursos históricos. Nada custa relembrar a Emenda Plate, de 1901, dando poderes aos Estados Unidos para invadir Cuba. Referida emenda, impregnada de conceitos da Doutrina Monroe, aplainou terreno para o aparecimento, em 1904, do Corolário Roosevelt acompanhado do odiado "Grande Porrete". Em substância, quase todo igual ao modelo do porrete agora exibido pelo texano George W. Bush, na selvagem cruzada contra o terrorismo.

Passado um século e pouco, o Big Stick reaparece no novo Far West, em versão modernizada, fortalecido com armas nucleares, porém imprestáveis na defesa da segurança interna. Confessadamente pouco eficazes para o sucesso da política antiterror estadunidense. Política desta vez dirigida não só para a surrada América Latina, vítima do narcoterrorismo, mas para toda a terra.

Infelizmente, são relativamente poucas as vozes clamando contra o uso da força militar no combate ao terror. A militarização do combate à violência do terrorismo fundamentalista e do narcoterrorismo é questionável. Até hoje não solucionou problema nenhum, porque a paz dos cemitérios não é a paz que se almeja nas relações internacionais.

A derrubada do muro de Berlim em 1989, símbolo do fim do poder bipolar significou a autodecomposição do comunismo burocrático. Abriu imediatamente as portas do mundo às insuficiências do poder unipolar. Quase sem barreiras, as transnacionais da violência atiçam contradições a favor do terror. A violência nutrese da degradação dos valores cristãos presentes na extremamente hedonista democracia estadunidense. Por tal razão, a luta contra as causas do terrorismo hodierno promete novas interpretações, não apenas às relacionadas à força militar, mas também às relacionadas à dominação econômico-cultural pelos países centrais, vale dizer, pelo senhorio das novas Romas com seus novos bárbaros.

A violência nas relações internacionais pressagia outro capítulo no velho livro conhecido como Destino Manifesto, há décadas estigmatizado por seu caráter tanto expansionista como intervencionista presente na ética capitalista dos Estados Unidos da América. O Destino Manifesto historicamente repleto de violações na América Latina dominou, pouco a pouco, o cenário internacional. Cobre de sombras o prestígio da moral estadunidense que, depois de décadas e décadas semeando influências, começa no novo milênio a colher reações políticas e ideológicas adversas.

A história promete ser dura, caso a presente diabolização do terror continue desacompanhada de ações para eliminar suas causas, se os conflitos submersos nas relações internacionais não forem igualmente atacados. Só que a sociedade dos países centrais não permanecerá como dantes, apenas como telespectadora: agora é também vítima. Suprimir as liberdades civis básicas, desrespeitar os direitos 
humanos na luta contra o terror equivalerá a colocar mais lenha na fogueira das contradições.

\section{Convenções antiterror e falhas no trato diplomático}

O narcoterrorismo e o terrorismo político provaram andar de mãos dadas. Em seu combate, somas bilionárias se consomem, pagas pelo contribuinte. Todavia, ao invés de políticas públicas para superação das contradições que geram conflitos, cuja manifestação maior tem sido a violência, se faz é esquecer a paz!

Com a guerra, o narcoterrorismo cresce. Suas fortes ramificações há anos minaram, em várias nações, as bases da democracia. $\mathrm{O}$ terror dos negócios das drogas mostra-se próspero. A prometida investida contra a lavagem do dinheiro fica só nas intenções. A luta contra o terror, capaz de soterrar o Afeganistão com bombas, é incapaz de reverter atitudes que dificultam o combate à lavagem de dinheiro e à produção da heroína.

As células ou grupos sustentadores de planos em categorias operacionais obtiveram, com a dita globalização, facilidades para execução de suas atividades criminosas. Depreende-se então, que o caráter transnacional do terrorismo pede políticas públicas de âmbito mundial contra o terror e não indústrias antiterrores que fabricam o terror. Políticas públicas a favor da paz implementadas preferencialmente sob a égide das Nações Unidas. Em todos os países, ricos e pobres diminuiriam então as cruamente expostas chagas das debilidades do trato diplomático internacional no combate ao terror.

A incompetência no âmbito das relações internacionais na construção de políticas para a paz e a não-violência abre portas para o uso da força na luta contra o terrorismo. Por exemplo, as conferências de Tóquio, em 1963, Haia, em 1970, Montreal, em 1971, a Convenção de Nova Iorque, em 1977, a Convenção Européia para a Supressão do Terrorismo, na cidade francesa de Estrasburgo e a Convenção de Genebra, ambas realizadas em 1977, mais a primeira Convenção Árabe de Luta Contra o Terrorismo no Cairo em 1998, todas quase nada aportaram em termos de iniciativas contra o terror internacional.

O Direito Penal Internacional, tal qual as convenções, no estado de natureza das relações internacionais hodiernas, é letra morta e assim continuará até que algo apareça para defender o mais fraco da lei do mais forte. Tomara que tal iniciativa não seja o próprio terror.

Limitadas e sem visão, preocupadas quase que exclusivamente com a proteção de autoridades diplomáticas, as mencionadas convenções apresentaram poucos resultados positivos para o mundo. $\mathrm{O}$ caráter cosmético dessas iniciativas da diplomacia reservou às citadas convenções medíocre espaço na arena internacional. Além de não terem conseguido número suficiente de adesões, enfrentaram a falta de ratificações. 
Questões básicas como soberania nacional, direito sem fronteira, razão de Estado, critérios para extradição e jurisdicionalidade permaneceram na estaca zero. A discussão do uso da força bruta utilizando ações unilaterais de combate ao terror ainda soava, nos tempos da bipolaridade e imediatamente após o seu fim, como verdadeira heresia a desfavor do outrora sagrado princípio da inviolabilidade territorial.

\section{Apropriação do nome de Deus}

A negligência dos países desenvolvidos com relação ao terrorismo das desigualdades nas relações internacionais precisa ser combatida, porque tal batalha manterá acesa a chama da indignação contra atos terroristas, contra suas causas. Ajudará na busca do consenso acerca da necessidade da eliminação do ódio.

Sabendo ser pouco demais o que a Organização das Nações Unidas realiza contra o terror, inclusive a desfavor das desigualdades por causa do seu obcecado temor diplomático de ferir susceptibilidades nacionais, a ONU, ao qualificar o terrorismo como crime internacional, chove no molhado. Variadíssimas interpretações podem ser dadas ao Artigo 51 da sua própria Carta, em que se reserva aos países o direito da autodefesa. O Iraque e a Líbia, por exemplo, estão roucos de tanto invocá-lo.

A domesticação do terror da violência com a banalização do valor da vida, em flagrante desrespeito ao próximo e aos direitos humanos, mais a apropriação do nome de Deus no combate ao terror entre as partes conflitantes - vejam-se, por exemplo, os discursos de George W. Bush e Osama bin Laden - complicam enormemente a arena da ética antiterrorista. A invocação do nome de Deus deveria preocupar as diferentes confissões religiosas. Sobre isso não se ouviu quase nada das lideranças eclesiásticas ocidentais, inclusive por parte do Vaticano. Relativamente poucas vozes nas igrejas checam a moralidade dos bombardeios lançados pela nação mais poderosa contra provavelmente uma das menos favorecidas. Apelar para a ética cristã é lembrar a onipresença divina manifestada tanto em Washington quanto em Cabul ou em Brasília.

O sentido espiritual da Jihad, Guerra Santa, precisa ser respeitado e conhecido no Ocidente. Jihad significa igualmente empenho em busca do equilíbrio a serviço do Criador; empenho traduzido como esforço de defesa dos valores da fé islâmica. A tradição maometana prega caminhar da Jihad menor para a Jihad maior. A Jihad maior é o empenho da fé e do exemplo. Também implica ascese testemunhal por meio de usos e costumes (suna) ensinados pelo Profeta, em Medina ${ }^{5}$.

Diferentes leituras aplicam-se à bíblia e ao corão. Fundamentalistas encontram-se tanto no islamismo, no judaísmo e no cristianismo, quanto no budismo. Misturar islamismo com terrorismo equivale a esquecimento da essência do radical 
monoteísmo abraânico presente no judaísmo, no islamismo e no cristianismo. Entender esta trilogia como se fossem civilizações em choque e de outro mundo, como pretende Samuel Huntington ${ }^{6}$, com suas cortinas de ferro, de bambu e de veludo, só reforça equívocos e preconceitos históricos transmitidos por ideologias compromissadas. Existe choque sim, mas de poder. Luta de classes, não de civilizações!

As elites dominantes ocidentais, convictas da morte e sepultamento do marxismo, acordam atônitas com o explodir das reações em cadeia às respostas fratricidas perpetradas pelo sofisticado aparato bélico industrial dos Estados Unidos. Destas ações, por condenáveis que sejam, ingente mérito não se pode negar: ressuscitaram a utopia marxista soprando vigorosamente o espírito da teologia da libertação.

Em nome de interesses toma-se o santo nome de Deus em vão. O abuso de Deus, seja pelos movimentos terroristas, seja pela repressão mundial ao seu encalço, certamente traduz conviç̧ões mais profundas que as estudadas até o presente na sociologia das relações internacionais. Por exemplo, o Miutzan Elohim (Ira de Deus) vingava o brutal assassinato de atletas israelenses nos Jogos Olímpicos de Munique em 1972, observando o "dente por dente, olho por olho" do ensinamento bíblico. Respondia com terror o terror do Setembro Negro de Yasser Arafat que, anos mais tarde, dividiria, com Shimon Perez o Prêmio Nobel da Paz.

O Ruhollah (Sopro Divino) dos xiitas iranianos, o Portão do Céu californiano, o Templo do Povo, causador de centenas de mortes por envenenamento, na Guiana, a Jihad Islâmica do Egito, o Hezbollah (Partido de Deus) no Líbano e o Hamas (Fervor) constituem modelos de manipulação do messiânico no desespero do terror. Fosse vivo, Antônio Conselheiro e seu bando de fanáticos sertanejos famintos talvez se confundissem com os talibãs afegãos integrando a lista da história terrorista dos presentes dias ${ }^{7}$.

\section{Direito de intervenção e terrorismo}

Direito de intervenção, soberania limitada e as novas, tais quais as antigas cruzadas assassinas de muçulmanos e de judeus, alteraram a fisionomia e expuseram a heterogeneidade da interpretação do significado da liberdade. A guerra com sangue de inocentes contra as redes do terrorismo organizado transformou princípios, notadamente os do centro mundial de poder, quase em ultrapassados símbolos éticos e morais.

Tomara que autoridades políticas nos Estados Unidos da América façam sua mea culpa pelos pecados no passado e no presente; redimam-se lutando a favor da solução estrutural dos problemas da segurança humana. A América Latina, dopada décadas e décadas nos conceitos e nos mitos da segurança hemisférica, terá dificuldades em levar suas elites dirigentes a ver que a distribuição da renda e 
a justiça social são, até agora, os realmente seguros instrumentos de superação das contradições sociais e o melhor antídoto contra a hodierna luta de classes, que poderá ter no terror seu braço forte.

$\mathrm{Na}$ lei da selva das relações internacionais, em que conflitos integram o seu quotidiano, há tempos deveriam estar prontos os arranjos para o pacto social a favor do entendimento contra o terrorismo internacional em suas variadas manifestações. Todavia, é impossível criar o pacto social na vigência do estado de natureza, na desordem das relações internacionais em que um país apoiado pela força de seus exércitos julga sem ser julgado, condena sem ser condenado; tem a coragem de proclamar "cada nação tem uma decisão a tomar. Ou está conosco ou com os terroristas"8. Tal contexto repete a velha política maniqueísta do bem e do mal.

Os formuladores da política antiterror estadunidense, com certeza, não fazem distinção entre seus bens e os dos outros. Thomas Hobbes tem razão. Pontuou não existir propriedade, nem império sobre coisa nenhuma. Nem distinção entre o que é teu e meu. Pertence ao homem só aquilo que ele consegue manter e tão somente durante o tempo em que pode defender ${ }^{9}$. Seu realismo e a visão filosófica de John Locke consideravam a violência como espécie contrária de justiça.

$\mathrm{Na}$ conjuntura internacional da violência, falta a proveitosa presença do Leviatã, monstro protetor dos pequenos contra o grande e poderoso predador. A metáfora hobbesiana aplaude a necessidade da ordem justa na desordem injusta presente no relacionamento internacional. Um estado de sociedade universal com justiça, seja ele o sonhado por Kant, Hegel, Marx ou Rousseau, com certeza minaria a força do terror. Poria a sociedade das nações nos trilhos da ordem justa. Resta saber qual Leviatã possuirá clarividência e ideal suficientes para mostrar à sociedade das nações os caminhos da paz e da prosperidade.

\section{Terror como continuação da política por outros meios}

A sociedade humana dispondo de uma Organização das Nações Unidas manietada, sequer lembrada nos discursos a favor da luta contra o terrorismo internacional, num contexto político em que Estado algum abre mão de suas prerrogativas a favor do governo universal, deveria recorrer ao realismo de Clausewitz ${ }^{10}$. Pode em brados afirmar que, na atualidade, ao invés da luta de uma nação contra outra, o terrorismo é a continuação da política por outros meios.

Observa-se então que no relacionamento internacional, pouco importa por parte de quem os equívocos da luta contra o terror pelo terror aportarão tempos de intolerância e irracionalidade. Contra tal política relembremos os tão consagrados Princípios da Filosofia do Direito, em que seu autor, o filósofo Hegel, mostra que Estado algum, povo algum pode atribuir-se, invocando sua pretensa representatividade, qualquer supremacia sobre outros povos ${ }^{11}$. 
Com a globalização da insegurança, a intolerância arma suas emboscadas: escuta apenas a voz daquele que grita mais alto. Em face das tantas vítimas dos diversos tipos de terror, que se lembre de Tertuliano. Transformemos sua afirmativa em objeto de reflexão nestes conturbados dias sem endereço dos refúgios da razão. "Sanguis martirum est semen cristianorum", sangue de mártir é semente de cristão. Esta máxima não se aplica apenas à civilização ocidental. $O$ fundamentalismo islâmico consegue, dentro de sua visão de mundo, incontável enormidade de fiéis prontos para morrer em nome da defesa de sua fé e de seus princípios religiosos. Daí o equívoco do combate do terror pela violência semeadora de terror.

\section{Tipologias do terror}

Os tupamaros uruguaios, o peruano Sendero Luminoso, a salvadorenha Frente Farabundo Marti de Libertação Nacional (FMLN), o filipino Novo Exército Popular e o malaio Partido Comunista, por décadas, foram rotulados de terroristas com inspiração maoísta. Também os sandinistas eram vistos como sinônimo de terror. Em seu combate, os Estados Unidos financiaram os "contras". Usaram a velha tática do terror contra terror sem nenhum respeito à soberania. Por seus atos, foram condenados pela Corte Internacional de Justiça da Haia e tudo continua na mesma.

A rebeldia curda na ex-União das Repúblicas Socialistas Soviéticas, no Irã, no Iraque e principalmente na Turquia considera-se como o que existe de pior no terrorismo. A perseguição implacável ao PKK, por razões geopolíticas, é ajudada por muitos e combatida por poucos. No México, o subcomandante Marcos não foge da rotulagem de terrorista apesar de suas ações radicais em favor das liberdades e dos direitos da maioria indígena em Chiapas. A Organização Militar Nacional (Irgun Zvai Leumi) ao explodir, em 1946, o quartel general das forças armadas imperialistas britânicas em Jerusalém com dezenas e dezenas de mortos, indignou os súditos da coroa e encheu de júbilo os judeus na reconquista de sua Terra Prometida. A maioria deles sobreviventes do terror do nacional-socialismo, vítimas do terrorismo dos campos de concentração, em que imperava o lema: "o trabalho liberta".

O Exército Revolucionário Irlandês (IRA) mais o ETA (Pátria Basca e Liberdade), colocados nos porões da tortura pela repressão do Reino Unido e da Espanha, fazem da resistência sua razão de vida. Pior de tudo, recebem o mesmo rótulo de movimento terrorista aplicado à Força Voluntária do Ulster (UVF) e ao Ulster Freedom Fighters, os dois últimos assassinos inclementes de católicos militantes.

A desintegração da Iugoslávia tampouco processou-se fora do alcance do terror, do processo chamado de limpeza étnica. O curioso na história do terrorismo é que suas extensões domésticas são tão potentes quanto seu formidável impacto 
externo. Suas manifestações, quer se queira ou não, influenciam as relações internacionais.

O Movimento de Resistência Afrikânder, grande caçador e matador de negros no apartheid, nunca foi considerado como movimento terrorista pelos racistas brancos da África do Sul e da antiga Rodésia. Para a elite dominante sul-africana, terrorista era o Congresso Nacional Africano.

Outro fato histórico a ser lembrado é o terrorismo das ditaduras militares de direita espalhadas entre 1960 e 1980 por toda a América Latina. No Brasil, por exemplo, o terror do regime militar contou com a ajuda de muitas burocracias na implementação da repressão. Inclusive a diplomacia brasileira não negou préstimos à ditadura a que tão lealmente serviu rastreando e denunciando as vítimas do golpe militar em exílio no exterior.

Outros exemplos atuantes: o Grupo Islâmico Armado (GIA) na Argélia, o Exército Vermelho Japonês e a Frente Nacional Islâmica Muhamad Gailani para a Libertação do Afeganistão, que serviu de escola para a atual militância talibã. A Aum Shirinkyo, no Japão, a Jihad Islâmica Palestina, o Grupo Abu Nidal, a AlFatah, a PLOTE (Organização Popular para a Libertação do Tamil), os Tigres Tamil no Sri Lanka, os Sikhs na Índia, a Frente de Libertação da Córsega e a Frente de Libertação do Quebec. Todos os grupos e movimentos citados ilustram o balaio de gatos ideológico da violência e da anarquia do terror nas relações internacionais ${ }^{12}$.

O narcoterrorismo presente na maioria dos países amazônicos mais parece um ninho de cobras. Envenena a sociedade por meio de assaltos a mão armada, bancos, estabelecimentos comerciais, seqüestros, roubo de carros e de cargas demonstrando incansável vitalidade. Pelas autoridades responsáveis, geralmente reprimido com insuficiente rigor, o fenômeno do narcoterror, verdugo das frágeis democracias latino-americanas, possui nas Autodefesas Unidas da Colômbia $(A U C)^{13}$ parte da sua sustentação. Também as FARC (Forças Armadas Revolucionárias Colombianas) e o ELN (Exército de Libertação Nacional), por suas ações extremamente próximas às fronteiras com o Brasil, transformaram-se em perigoso instrumento de instabilidade política na região amazônica, notadamente entre colombianos, brasileiros e venezuelanos.

Definir tanto a natureza quanto as características do terrorismo, diferenciar os velhos dos novos atos de terror é tarefa complexa porque complexas são as diversas causas e origens do terrorismo. Na geopolítica internacional, os olhares sobre o terrorismo tampouco continuam os mesmos. Por exemplo, os "freedom fighters" antes considerados como heróis da resistência afegã em luta contra os soviéticos são, hoje, vistos como concentração de barbárie.

Nem sempre foram as mesmas as reações da sociedade internacional em face das ações do terror contra o poder e também do terror contra os mais fracos. Nem a Ku Klux Klan e nem a Milícia de Michigan, com suas mortes enterradas no 
esquecimento da opinião pública, conseguem ser menos lembradas que o virulento terror congolês. Paradoxalmente o mais esquecido de todos, o terrorismo no Congo mata por dia aproximadamente duas mil e quinhentas pessoas, bem próximo do correspondente ao número de mortos ocorrido numa das torres do World Trade Center.

\section{O terror da omissão}

Nesta reflexão, acrescente-se que, nas relações internacionais, também se vive o terrorismo da omissão, aproveitando-se da assimetria e da capacidade acrítica da desordem mundial. A consciência adormecida do processo civilizatório em pleno início do século XXI, cala em face de atos terroristas perpetrados por rebeldes apoiados por Angola, Zimbábue e Namíbia contra o igualmente terrorista exército do Congo, escorado por tropas de Ruanda e Uganda.

As cinzas, ainda quentes, dos conflitos étnicos em Biafra, Ruanda e Burundi, de hútus contra tutsis e vice-versa, ardem. Apesar disso, não se conhece nenhum gesto de abrangência mundial contra o terror que nos últimos três anos ceifou dois milhões e quinhentas mil vidas na parte oriental do Congo.

A opinião pública mundial e a mídia propositadamente deslembram a realidade do mundo de ser de todos para todos; que o sentimento não é exclusividade dos países de primeira classe. O número de vítimas nos países excluídos é maior nas mãos do terror. Triste é esquecer que fazer mártires, não importa onde e nem em favor de que causas, só serve para aumentar o sacrifício dos martírios.

$\mathrm{O}$ terrorismo usado tradicionalmente nas guerras é fenomenologia antiga na história da humanidade, anterior ao aparecimento dos Estados nacionais nos séculos XV e XVI. Na falta da ordem e do estado de justiça, a Antigüidade viu o terror como instrumento de barganha e até de esperanças. No atual contexto de desordenamento internacional, com a globalização selvagem debilitando os Estados nacionais, a história parece repetir a intrínseca natureza transnacional das diversas formas de terror em ação. Tanto o narcoterrorismo quanto o terrorismo religioso encontram na unipolaridade globalizadora do poder mundial campo fértil para sua extensão vertical e horizontal no seio das nações.

O terrorismo da violência espalhado pelas casas e ruas das cidades latinoamericanas, assim como o terrorismo da corrupção, profundamente enraizado nas instituições nacionais, criam aqui e em outros países globalizados sentimentos de impotência e passividade. A violência interna, somada a outras patologias do terror presentes na periferia mundial, tão amoral quanto a marca do terror nos países centrais, deixa de assustar por não despertar o clamor da mídia e nem da opinião pública. Isto porque o terror periférico geralmente sacrifica, na maioria das vezes, pobres, excluídos e miseráveis. 
Os imolados pelo extremamente letal terror do subdesenvolvimento encontram-se em número incomparavelmente superior ao das vítimas do terror no mundo desenvolvido. A diferença é que este opróbrio, que também é o terrorismo da fome e da exploração do homem pelo homem, está propositadamente esquecido pela hipocrisia do sistema internacional, hipocrisia destruidora do que ainda resta da coragem civil pelos cantos da terra.

\section{Do anarquismo ao terrorismo}

A descrição das construções interparadigmáticas tricotada em torno do fenômeno do terror é exercício explicativo sujeito a equívocos. Mesmo assim, valeria a pena tecer algumas considerações a respeito. Acontecimentos históricos para subsidiar tal análise não faltam. Por exemplo, durante o século XIX até meados da segunda parte do século XX, o Ocidente confundia anarquismo com terrorismo. Possivelmente porque os anarquistas, de forma menos condescendente que os marxistas, sempre lutaram pela radical eliminação do Estado nacional, coisa que agora a globalização impiedosamente executa sem perseguição alguma contra ela.

A utopia anarquista, dentre as utopias, talvez tenha sido a mais reprimida. O suicídio montado na prisão alemã de Stammheim contra a liderança da Facção do Exército Vermelho, somado ao fim dado às Brigadas Vermelhas, na Itália, deu provas de ações nada democráticas contra o anarquismo em nome da razão de Estado.

O cenário do terror da guerra dos países centrais na periferia mundial, apesar de todas as vantagens da tecnologia, recomenda lembrar que "na guerra os números por si só não conferem vantagem alguma. Não avances confiando no mero poderio militar" 14 . A advertência proclamada por Sun Tzu cerca de meio milênio antes da era cristã pode ser aplicada nos momentos atuais, em que a noção do valor heurístico passa por rápidas mutações. O mesmo ocorre com a sociedade e as ideologias revolucionárias. "A relação com os valores, a idéia que se faz, por exemplo, de uma época ou de uma doutrina sob a forma do idealtipo, a fim de captar sua significação, não corresponde forçosamente à idéia que os contemporâneos daquela época ou os militantes daquela doutrina faziam delas"15. Assim, nada impede que a perseguição movida na caça a Osama bin Laden o promova a mártir, se ele for morto e em herói se continuar vivo. Em ambos os casos, no ídolo que o terror fundamentalista islâmico tanto anseia. Tal qual ocorreu na bárbara repressão levada a cabo pelas ditaduras militares latino-americanas, responsáveis pela transformação de Ernesto Che Guevara em herói e mártir para milhares de latino-americanos e europeus, entre outros.

Com a contribuição da análise por meio de reflexões formuladas entre outros por pensadores como Michail Bakunin, Peter Kropotkin, Pierre J. Proudhon, William Godwin, Elisée Reclus, Leo Tolstoi, Errico Malatesta, John Most, Emma 
Goldman, Gustav Landauer, Erich Mühsan e Rudolf Rocker, a substância teórica do anarquismo brotou em mananciais nos quais movimentos terroristas, principalmente europeus, saciaram sua sede teórico-explicativa ${ }^{16}$.

O lema do grupo Baader Meinhof, "destrua o que vos destrói” reapresentase, agora, despojado ou não da ideologia do materialismo dialético, renovado em versões messiânicas, como por exemplo, a morte em nome da fé, o sacrifício da vida em nome da salvação etc. A audácia dos terroristas de hoje, mutatis mutandis, parece imbuída de coragem, sem dúvida diferente, porém não menos audaciosa que a dos cristãos mortos no Coliseu contra a ordem pagã e o hedonismo do Império Romano.

Dos anarquistas nasceram idéias, sonhos, quase todos transformados em pesadelo por causa da repressão. Por exemplo, o mencionado macht kaputt was euch kaputt macht, destrua o que vos destrói, bandeira da Facção do Exército Vermelho, fez tremer as bases de democracias criadas no pós-guerra sobre os escombros da derrota nazista. Significou o grito de expressivo segmento da juventude ocidental rica e hedonista impressionada com a desnecessária carnificina das guerras. Paralelamente a isto, a angústia existencial dos anos dourados bipartia a juventude entre "alienados" e "revolucionários".

$\mathrm{Na}$ alienação buscou-se o consolo nas drogas e na despolitização o silêncio dos injustiçados. Alienação e despolitização versus militância sadia, como a conhecida na expansão mundial dos protestos estudantis nascidos na França em 1968, por paradoxal que pareçam, transformaram-se em sementes para posterior germinação do terror, inclusive em países onde não se negam condições à mocidade de expressar com certa liberdade suas reivindicações.

\section{Conclusão}

Não basta qualificar vertentes do terror, entre outras de narcocriminal, cibernética, pluralista, financeira, igualitária, repressiva, religiosa, separatista e revolucionária. Proceder à rotulação como a aplicada ao bioterrorismo manipulador do Bacillus Anthracis, ou formular novas tipologias básicas do terrorismo no cenário internacional, separadamente da explicação estrutural da fenomenologia da dominação e da luta de classes, mostrará ineficácia no trato analítico. Seguramente, além da observação da máquina do terror, a visão analítica das estruturas hodiernas da indústria da violência nas relações internacionais, longe de pura ponderação metafísica, contribuirá para o diagnóstico dos porquês do tão precoce agravamento da degenerescência da democracia no trato do terror gerado em suas entranhas. A civilização ocidental cristã, ao não aplicar os princípios de sua moral e sua ética, tolera a injustiça. Tolerando injustiças, transforma-se em hospedeira nata do vírus da delinqüência. 
A natureza indiscriminada do terror hodierno atacando alvos, com e sem especificidades, semeia o medo propagando o mal como a papoula entre o trigo. $\mathrm{O}$ medo provou ser a droga nociva das relações internacionais sob a unipolaridade, porque acovarda a sociedade. Mais penoso do que isso, o desiderato de cada nação em salvar a si própria leva à falta de solidariedade e fertiliza a mútua incompreensão entre os povos na luta contra o terror. Não menos grave é o renascer da crença na mensagem do homo homini lupus, homem lobo do homem. Dá a falsa idéia de que o construído por mãos humanas é negativo e sujo e de que a visão kantiana da paz perpétua não passa de sonho.

$\mathrm{Na}$ sociedade das nações conhece-se cada vez mais a história das coisas e dos fatos. Em contrapartida, é menor o espaço para o exercício da cidadania do homem que quotidianamente torna-se menos sujeito da sua própria história. Talvez por isso os valores e os ideais avançam movidos por cobiça e dominação colocando em risco as esperanças no futuro da segurança humana. Desgraçadamente, tais fatos reforçam os individualismos nacionais. Tornam remota a certeza da vitória na luta contra o terror no caminho repleto de armadilhas das relações internacionais sob o signo da lei do mais forte.

Outubro de 2001

\section{Notas}

1 Procópio, Argemiro. O Terrorismo e a Segurança.. Correio Braziliense. Brasília, 23.09.2001, p.10.

2 Procópio Argemiro. L'Amazonie et la mondialisation - Essai d'écologie politique. Paris: Ed. L'Harmattan, 2000.

3 Procópio, Argemiro (org.) Narcotráfico e Segurança Humana. São Paulo: Ed. LTR., 1999, p. 86.

4 Procópio, Argemiro. O Brasil no mundo das drogas. Petrópolis: Ed. Vozes., 1999, p.199.

5 Ver: Bartholo Jr., Roberto S. e Campos, A. E. (orgs.), Islã. O credo é a conduta. Rio de Janeiro: Editora Imago, 1990.

6 Ver: Huntington, Samuel. O Choque das Civilizações. Editora Objetiva.

7 Ver: Cunha, Euclides: Os Sertões. Editora Record..

8 Discurso do Presidente George W. Bush, no Congresso dos Estados Unidos da América, em 20 de setembro de 2001.

9 Hobbes de Malmesburry, Thomas: Leviatã ou Matéria, Forma e Poder de um Estado Eclesiástico e Civil. São Paulo: Ed. Abril Cultural, 1983.

10 Ver: Clausewitz, Carl von. Penser la guerre. Paris: Gallimart, 1976.

11 Hegel, Georg Wilhelm Friedrich. Principios da Filosofia do Direito. Editora Martins Fontes.

12 Ver Degaut Pontes, Marcos Rosa. "Terrorismo: Críticas, Tipologia e Presença nas Relações Internacionais.” Dissertação de Mestrado em Relações Internacionais, Brasília, Fevereiro de 1999, p. 37 a 88.

13 Procópio, Argemiro. Estado, Soberania e o Plano Colômbia. Tempo e Presença., n. 318, Rio de Janeiro, Ano 23, Julho/Agosto de2001, p 15.

14 Tzu, Sun. A Arte da Guerra. Rio de Janeiro: Editora Paz e Terra, 1997, p.99. 
15 Freund, Julien. Sociologia de Max Weber. Rio de Janeiro: Companhia Editora Forense, 1970, p.52.

16 Bakunin, Michail. Freiheit und Sozialismus. Impressum/Liberdad-Verlag. Anarchistischer Bund Berlin. 1978; Kropotkin, Peter. Gesetz und Autorität. Impressum/Liberdad-Verlag. Anarchistischer Bund Berlin. 1978; Proudhon, Pierre J. Eigentum ist Diebstahl. Impressum/ Liberdad-Verlag. Anarchistischer Bund Berlin. 1978; Godwin, William. Über die Politische Gerechtigkeit. Impressum/Liberdad-Verlag. Anarchistischer Bund Berlin. 1978; Reclus, Elisée. Evolution und Revolution. Impressum/ Liberdad-Verlag. Anarchistischer Bund Berlin. 1978; Tolstoi, Leo. Patriotismus und Regierung. Impressum/ Liberdad-Verlag. Anarchistischer Bund Berlin. 1978; Malatesta, Errico. Anarchismus-Syndikalismus. Impressum/ Liberdad-Verlag. Anarchistischer Bund Berlin. 1978; Most, John. Kommunistischer Anarchismus. Impressum/ Liberdad-Verlag. Anarchistischer Bund Berlin. 1978; Goldman Emma. Anarchismus - Seine Wirkliche Bedeutung. Impressum/ Liberdad-Verlag. Anarchistischer Bund Berlin. 1978; Landauer, Gustav. Staat und Geist. Impressum/ Liberdad-Verlag. Anarchistischer Bund Berlin. 1978; Mühsam, Erich. Der Geist der Freiheit. Impressum/ Liberdad-Verlag. Anarchistischer Bund Berlin. 1978; Rocker, Rudolf. Anarchismus und Organisation. Impressum/ Liberdad-Verlag. Anarchistischer Bund Berlin. 1978.

\title{
Abreviaturas
}

\author{
AUC - Autodefesas Unidas da Colômbia \\ ELN - Exército de Libertação Nacional \\ ETA - Pátria Basca e Liberdade \\ Estados Unidos - Estados Unidos da América \\ FARC - Forças Armadas Revolucionárias Colombianas \\ FMLN - Frente Farabundo Marti de Libertação Nacional \\ GIA - Grupo Islâmico Armado \\ IRA - Exército Revolucionário Irlandês \\ OCDE - Organização para a Cooperação e Desenvolvimento \\ Econômico \\ OEA - Organização dos Estados Americanos \\ ONU - Organização das Nações Unidas \\ PLOTE - Organização Popular para a Libertação do Tamil \\ PKK - Partido dos Trabalhadores do Kurdistão \\ TIAR - Tratado Interamericano de Assistência Recíproca \\ UVF - Força Voluntária do Ulster
}

\section{Bibliografia}

BAKUNIN, Michail. Freiheit und Sozialismus. Impressum, Liberdad-Verlag. Anarchistischer Bund, Berlin, 1978.

BARTHOLO Jr., Roberto S. e CAMPOS, A. E. (orgs.), Islã. O credo é a conduta. Editora Imago, Rio de Janeiro, 1990.

BUSH,George W. Discurso do Presidente no Congresso dos Estados Unidos da América, em 20 de setembro de 2001.

CLAUSEWITZ, Carl Von. Penser la guerre. Paris, Gallimart, 1976.

CUNHA, Euclides: Os Sertões. Editora Record, $2^{\text {a }}$ edição. 
DEGAUT PONTES, Marcos Rosa. Terrorismo: Críticas, Tipologia e Presença nas Relações Internacionais. Dissertação de Mestrado em Relações Internacionais, Brasília, Fevereiro de 1999.

FREUND, Julien. Sociologia de Max Weber. Rio de Janeiro, Companhia Editora Forense, 1970.

GODWIN, William. Über die Politische Gerechtigkeit. Impressum. Liberdad-Verlag. Anarchistischer Bund Berlin, 1978.

GOLDMAN, Emma. Anarchismus - Seine Wirkliche Bedeutung. Impressum. Liberdad-Verlag. Anarchistischer Bund Berlin, 1978

HEGEL, Georg Wilhelm Friedrich. Princípios da Filosofia do Direito. Editora Martins Fontes.

HOBBES, Thomas: Leviatã ou Matéria, Forma e Poder de um Estado Eclesiástico e Civil. $3^{\mathrm{a}}$ ed. São Paulo: Ed. Abril Cultural, 1983.

HUNTINGTON, Samuel: O Choque das Civilizações. Editora Objetiva.

KROPOTKIN, Peter. Gesetz und Autorität. Impressum. Liberdad-Verlag. Anarchistischer Bund Berlin, 1978.

LANDAUER, Gustav. Staat und Geist. Impressum. Liberdad-Verlag. Anarchistischer Bund Berlin, 1978.

MALATESTA, Errico. Anarchismus-Syndikalismus. Impressum. Liberdad-Verlag. Anarchistischer Bund Berlin, 1978.

MOST, John. Kommunistischer Anarchismus. Impressum. Liberdad-Verlag. Anarchistischer Bund Berlin, 1978.

MÜHSAM, Erich. Der Geist der Freiheit. Impressum. Liberdad-Verlag. Anarchistischer Bund Berlin, 1978.

PROCÓPIO, Argemiro.O Terrorismo e a Segurança. In: Correio Braziliense. Brasília, 23.09.2001, p. 10 .

PROCÓPIO, Argemiro (org.) Narcotráfico e Segurança Humana. Ed. LTR. São Paulo, 1999.

PROCÓPIO, Argemiro. O Brasil no mundo das drogas. $2^{\text {a }}$ edição.Ed. Vozes. Petrópolis, 1999.

PROCÓPIO, Argemiro: Estado, Soberania e o Plano Colômbia. Em: Tempo e Presença. nr 318 Koinonia. Rio de Janeiro, Ano 23 Julho/Agosto de2001.

PROUDHON, Pierre J. Eigentum ist Diebstahl. Impressum. Liberdad-Verlag. Anarchistischer Bund Berlin, 1978.

RECLUS, Elisée. Evolution und Revolution. Impressum. Liberdad-Verlag. Anarchistischer Bund Berlin, 1978.

ROCKER, Rudolf. Anarchismus und Organisation. Impressum. Liberdad-Verlag. Anarchistischer Bund Berlin, 1978.

TOLSTOI, Leo. Patriotismus und Regierung. Impressum. Liberdad-Verlag. Anarchistischer Bund Berlin, 1978.

TZU, Sun. A Arte da Guerra. Rio de Janeiro. Editora Paz e Terra, 1997.

\section{Resumo}

Análise do terrorismo como variável das relações internacionais. Referese o fenômeno aos atentados sofridos pelos Estados Unidos em 11 de setembro de 2001. Considera-se a reação norte-americana e os bombardeios do Afeganistão como estratégia inadequada de combate ao terrorismo, por desconsiderar suas causas, que repousam nas desigualdades entre as nações e nos descontentamentos sociais. 
Abstract

Analysis of the terrorism as a variable of international relations. It refers the phenomenon of the attacks suffered by United States on the $11^{\text {th }}$ of September of 2001. It considers the North American reaction and the attacks to Afghanistan a inadequate strategy to combat terrorism, for disrespect its causes, that rest in the inequalities among the nations and the social dissatisfactions.

Palavras-chave: Terrorismo. Ordem Internacional. Relações Internacionais. Key Words: Terrorism. International Order. International Relations. 